\title{
Norma e variação linguística: implicações no ensino da língua portuguesa em Angola
}

\author{
Ezequiel Pedro José Bernardo
}

Universidade 11 de Novembro-Angola

Instituto Superior de Ciências da Educação - ISCED/Cabinda

\section{Introdução}

Angola é um mosaico cultural complexo onde coabitam cerca de vinte línguas nacionais que o atribui características próprias de um país multilíngue. Para além do Português, há várias línguas africanas, com destaque as do grupo bantu, que circulam no território angolano. Dessas, as mais faladas são o Umbundu (22\%), o Kikongo (8\%), o Kimbundu (7\%), o Cokwe (6\%), o Nhaneka (3\%), o Ngangela (3\%), o Fiote (2\%), o Kwanhama (2\%), Muhumbi (2\%), Luvale (1\%) e outras línguas que representam (3\%) (INE, 2014). Embora exista cerca de vinte línguas nacionais, o Português é a única língua oficial, de ensino e de uso nas diversas esferas da vida social, o que a leva a possuir (71\%) de falantes, isto segundo os dados do último Censo Geral da População e da Habitação realizado em 2014.

A confluência linguística que caracteriza o país tem suas implicações no processo de ensino, uma vez que todo um conjunto de interferências resultantes do contato linguístico propicia o surgimento de uma variedade de Português cujo sistema léxico, fonético e fonológico, construções sintáticas, morfológicas e semânticas, não obedecem a norma do Português Europeu (PE). Deste modo, em Angola discute-se, nos últimos anos, a existência de um Português Angolano (PA), devido ao fato de o mesmo apresentar formas próprias que foram atestadas por vários autores, como por exemplo, Mingas (2007), Nzau (2011), Domingos (2011), Miguel (2014) e Adriano (2015). Angola, com suas especificidades linguísticas, vive um processo inicial, tal como se viveu no Brasil, para definir seu padrão de português alheio ao padrão europeu.

O PA é fruto da variação linguística, que, consequentemente, junto com a norma, são questões que têm sido amplamente discutidas nos últimos tempos por investigadores e professores devido a sua implicação no processo de ensino e aprendizagem em Angola. Isso mostra o carácter evolutivo e dinâmico da língua, 
bem como até que ponto as condições sociais, históricas (contactos), geográficas influenciam a produção discursiva dos indivíduos. Ora, ao descrevermos a variação linguística, acabaremos debruçando-nos também sobre a mudança linguística por esses dois aspectos estarem intimamente ligados. A abordagem da temática que nos propusemos a discutir será efectuada na perspectiva da Sociolinguística pelo fato de ela observar as línguas no seu viés social, isto é, heterogêneo, frisando uma realidade concreta que descreve os discursos reais dos falantes. Assim, a heterogeneidade tem relação intrínseca com a variação linguística, ou seja, a variação linguística admite vários usos dos recursos expressivos que se encontram à disposição dos falantes.

Não se deve olhar a realidade angolana como homogênea, visto que a diversidade linguística a torna heterogênea. Desta forma, é necessário que se reconheça que o ensino se volte à análise reflexiva e crítica da língua, que tenha em atenção o carácter social de uso que ela acarreta e que estabelece interação comunicativa entre os participantes do processo comunicativo (emissor e receptor). O ensino afincado na variação linguística reforça a ideia de que "o compromisso do educador é, antes, com a formação do aluno, com o desenvolvimento de suas capacidades tanto de reflexão sobre a linguagem quanto de uso crítico da língua" (Bagno, 2007, p.15). Assim, a vida social do indivíduo tem toda a relação com a língua, pois esta está intrinsecamente associada à maneira de ser e de ver o mundo.

Tendo em conta o que se descreveu até aqui, o trabalho objetiva: (i) proporcionar ao professor subsídios que estimulem a reflexão, questionamentos e a crítica sobre questões normativas com vista a um viés de ensino voltado à variação linguística; (ii) saber de que forma a norma-prescritiva pode implicar no ensino do PA; e (iii) apresentar marcas do português falado em Angola. Com base nos objetivos traçados, levantamos quatro questões que poderão nortear o estudo: Como estimular a reflexão, o questionamento e a crítica sobre questões normativas para um viés de variação linguística? Quais as marcas que se podem observar no português falado em Angola? Que implicações a norma-prescritiva pode provocar no ensino quando o país é marcado por variação linguística? Que português ensinar na escola?

Estas questões são levantadas pelo facto de o ensino da língua portuguesa em Angola estar baseado nas normas gramaticais como a única que se deve ter em conta como norma prescritiva imposta pela gramática tradicional. Esta forma de observação descarta as realidades que se vive com a língua em uso, que muitas vezes não obedece tais normas. No entanto, é notado que o ensino da língua tem se tornado empecilho no desenvolvimento das capacidades do aluno para compreender a língua de forma mais abrangente. 
Em termos metodológicos, o presente artigo cingir-se-á em uma pesquisa de carácter bibliográfico que apresenta discussões concernentes à norma e à variação linguística bem como suas implicações no processo de ensino da língua. Tentamos, igualmente, descrever os fenômenos que ocorrem na língua, motivados pelo contacto de línguas, fatos sociais, culturais, políticos e econômicos.

\section{Norma: agregadora ou segregadora?}

Vários estudiosos e pesquisadores têm abordado questões ligadas à norma linguística. Sobre este tópico, Monteagudo (2011, p.40-41) atesta que podem ser observadas duas tipologias de norma: a objetiva e a prescritiva. Esta distinção se torna mais fácil quando apresentada em dois adjetivos derivados, sendo, normal, que tem a ver com corrente ou rotineiro - adjetivo que pode se traduzir em termos de frequência estatística; frente a normativo, tendente a uma regra ou modelo, isto é, prescritivo. A variante normal perante uma variedade linguística é a mais frequente na produção de textos, enquanto a variedade normativa é de uso obrigatório em determinados tipos de variedades conforme determinado código ou regulação. $\mathrm{O}$ autor acrescenta que a norma objetiva tem carácter implícito e que se manifesta no uso da língua, o que implica dizer que ela é observável na atividade linguística de grupos sociais ou numa situação comunicativa. Já a prescritiva refere-se a regras imperativas, instruções e recomendações num corpo metalinguístico (gramáticas, dicionários, livros didácticos e outros textos). É remitente ao normativo o designado correto e o que é recomendado como aconselhável, o que implica dizer que existe o desaconselhável e o incorreto. Assim, considera-se a prescritiva como variedade ou norma-padrão que "se situa mais no domínio da potencialidade, da expectativa, da coisa imaginada e suposta do que do domínio da experiência efectivada" (Antunes, 2007, p.92).

De forma a compreender as particularidades existentes em torno das definições de norma acima descrita, recorremos à perspectiva de Antunes (2007, p.86) que sustenta existir dois tipos de normas, a norma como regularidade e a norma como prescrição. A primeira é correspondente ao regular, ao usual, de uso frequente das pessoas. Para esta autora, a norma linguística implica o conceito de normalidade e não o considerado certo ou errado. Já de maneira restrita, a norma como prescrição tem implicância ao conceito de normatividade, o de uso como deve ser, obedecendo parâmetros estabelecidos. Deste modo, fica clara a existência da norma objetiva/regular e da norma prescritiva/normativa.

Tratando-se de uma realidade multilíngue que veicula os aspectos socioculturais, o carácter normativo/prescritivo da língua não se enquadra no contexto em questão, o que implica dizer que a norma do PE, que é ensinada nas escolas 
angolanas, não espelha a realidade concreta do uso da língua. Os estudos que até então abordam o aspecto sociolinguístico ainda não estão publicados em Angola, deste modo, pouco ou nada se fala a respeito de uma abordagem das questões que se prendem à língua sob um viéis social, cultural e, quiçá, de políticas da variação ou mudança linguística. Todas essas questões não se podem ignorar no ensino, visto que possibilitam a crítica e os questionamentos das crenças linguísticas estabelecidas pela norma-prescritiva/padrão. Assim, propomos que a sala de aula deva tornar-se uma oficina reflexiva, questionadora, de modo a desconstruir o centralismo dado à norma-prescritiva/padrão. O professor deve ser o veículo que permite esta reflexão de forma que as variações linguísticas sejam parte das abordagens no ensino da língua portuguesa, visto que elas espelham a língua em uso. Deste modo, concordamos com o ponto de vista segundo o qual,

se essa regra é tida como errada, é simplesmente porque ela é diferente da regra única, categórica (e, muitas vezes, anacrônica), imposta pela tradição gramatical normativa, que se baseia exclusivamente nos usos linguísticos de uma elite de falantes mais letrados (Bortoni-Ricardo, 2004, p.9).

As normas objetivas e as prescritivas são designações que espelham uma ideologia linguística em que a primeira envolve o uso real da língua e a segunda tem a ver com o modelo imposto pelas normas do PE que resulta dos grupos com maior nível de escolaridade e de domínio comunicativo. Todavia, a "sociolinguística dá ao termo língua (um feixe de variedades): a norma-padrão é um construto sociocultural, portador-perpetuador de uma ideologia linguística, muito mais até do que um guia normativo para se falar e escrever corretamente" (Bagno, 2007, p.19).

Tratando-se de uma variedade que se distancia cada vez mais do PE, exatamente por agregar características próprias, motivadas pelo contacto linguístico entre as línguas nacionais e a língua portuguesa, vão surgindo formas próprias do PA. Com este fato, há uma necessidade de o professor abandonar o conservadorismo, pois essas visões puristas impossibilitam a flexibilidade e um debate aberto, de modo a incorporar as diversas alterações que forem surgindo, ou seja, não se pode aceitar que as variações linguísticas estejam a motivar o declínio da língua gerando, deste modo, a subjugação e ridicularização da mesma. Em todo caso, o professor é chamado a levar em sala de aula as abordagens relacionadas não só à norma-prescritiva/padrão, mas que envolva a variação linguística, relacionada à norma-objetiva/normal.

Entendemos que o professor, o investigador de questões relacionadas à sociolinguística, deve ter seu foco de ação na desconstrução das ideologias linguísticas arcaicas e conservadoras "que não se apoiam nos usos reais que as pessoas fazem 
da língua" (Antunes, 2007, p.93). É necessário que haja um reconhecimento da diversidade linguística inerente à sociedade angolana, de modo que as realidades de variação linguística sejam observadas, pois a norma "qualquer que seja, não pode ser compreendida apenas como um conjunto de formas linguísticas [variantes]; ela é também (e principalmente) um agregado de valores socioculturais articulados" (Faraco, 2002 apud Monteagudo, 2011, p.42).

No entanto, uma vez que a escola parte dos olhares da norma-prescritiva, que se considera como o "certo", o "correto" e o "aceitável", para a realidade angolana, observa-se que ela não surte efeito e torna-se segregadora, porque relega a língua em uso, isto é, a língua vista como interação social, que não se limita simplesmente a aspectos linguísticos e gramaticais. Logo, é necessário que se olhe para o lado social da língua de formas a desconstruir as ideias normativas vistas

\footnotetext{
como fenômeno interno à língua, como coisa simples, bem definida e bem controlável. É bom ainda porque nos leva a perceber que o uso da norma culta/prescritiva, por si só, não é garantia de boa linguagem. Toda a questão linguística vai além de constituir um simples rol de palavras e regras; é, portanto, mais que um inventário de erros e acertos. É algo que entra pelo terreno do social, do cultural, do político, do simbólico, de suas representações e valores (Antunes, 2007, p.90-91).
}

Pelo exposto, neste ponto, percebe-se que a norma se torna segregadora, suas razões são bastante complexas, mas motivadas pelas (i) políticas linguísticas adotadas pelo Estado; (ii) reduzido número de quadro docente formado para lecionar língua portuguesa e lidar com questões sociolinguísticas; (iii) professores sem formação na área. Estes são alguns dos fatores que contribuem ao ensino da gramática tradicional, o que promove a descriminação de valores sociais atribuídos a cada variedade linguística e a exclusão social dos alunos.

\section{Variação linguística}

As questões tendentes a prestigiar a norma-prescritiva do Português nas escolas angolanas, relegando a existência de variações, tem se tornado um problema que aflige os alunos. Esta abordagem, de alguma forma, tem sido promovida principalmente pelo Estado, pelos professores que adotam um ensino tradicional e se esquecem das variedades dialectais que a língua tem e que devem ser usadas de forma que os alunos absorvam e ampliem seus conhecimentos sobre as línguas e de aspectos a ela ligados. Deste modo, urge a necessidade de se aplicar o uso da variação linguística nas práticas de ensino, uma vez que se deve valorizá-la durante o processo de aprendizagem. Há que reconhecer que é esta variedade que dá cunho ao que designamos por PA. O ensino de língua portuguesa, neste caso, deve se pautar por uma visão abrangente, que aborde também a variação 
linguística, visto que o ensino de língua é um dos aspectos mais profundos na transformação do perfil socioeconômico e cultural dos sujeitos/falantes que frequentam as escolas (Bagno, 2007).

Ora, pensamos que é necessário desconstruir a homogeneidade que se atribui à língua, pois ela, como organismo vivo, pode variar sob diversas perspectivas de forma gradativa. Este processo gradativo do PA envolve as línguas nacionais e o Português, permitindo que se estabeleça o que a Sociolinguística defende e propõe como a heterogeneidade linguística e a heterogeneidade social, isto é, língua e sociedade são vistas como interdependentes, uma influencia a outra, isto é, a interação entre o indivíduo e sociedade motiva a mudança no sistema linguístico bem como no seu uso, como sugere Labov (2008). Sobre a heterogeneidade linguística, Bagno (2015, p. 27), reforça que "não existe nenhuma língua no mundo que seja "una", uniforme e homogênea. O monolinguismo é uma ficção". Fica patente que a incompreensão deste aspecto motiva os equívocos que se tem levantado em torno do ensino da língua portuguesa em Angola, pois se têm menosprezado as variações linguísticas e a norma-objectiva e considerando a norma-objectiva a forma errada.

\subsection{Variação linguística: caso de Angola}

As comunidades linguísticas são distintas umas das outras e é a partir de diversos aspectos e contextos de uso de sua língua que se observa o que designamos por variação linguística, como vem descrevendo Nzau (2011, p.64), ao afirmar que "o português falado atualmente em Angola é uma variante que expressa a angolanidade, uma característica enriquecida pelo perfume das línguas africanas que lhe conferem uma sonoridade melódica, contendo, desde já, traços próprios proporcionadores de existência autónoma".

Uma variável sociolinguística é algum elemento da língua, alguma regra, que se realiza de maneiras diferentes, conforme a variedade linguística analisada. Cada uma das realizações possíveis de uma variável é chamada de variante. A definição mais simples de variante é a de "cada uma das formas diferentes de se dizer a mesma coisa" (Bagno, 2007, p.50). No contexto do nosso estudo, a visão de Nzau (2011) sobre a variante é aplicável a questões fonéticas-fonológicas visto que estas apresentam alterações. No que tange às de carácter morfológicos, sintáticos e lexicais, esse contexto não se aplica devido à uniformidade que se verifica nas construções frásicas de vária ordem.

Por detrás de todo o tipo de variação linguística há sempre uma motivação. Esta motivação explica, explícita ou implicitamente, o porquê de uma determinada variação. Este fato é apontado por Antunes (2007, p.95), ao considerar que "no 
domínio das línguas, nenhuma mudança é aleatória, fruto do acaso. Cada uma tem sua lógica e sua motivação. Facilmente se pode explicar por que um item ou um padrão são substituídos por outros" (Antunes, 2007, p.95). O contacto das línguas nacionais com o português motivou a diversidade linguística que caracteriza Angola. Por esta razão, resolvemos descrever algumas feições que caracterizam o PA e os diferencia do PE. Para tal, recorremos ao Kimbundu para estabelecer uma comparação, por ser uma das línguas nacionais com mais estudos e por ser

\footnotetext{
no universo das línguas de origem africana de Angola, aquela que mais influência tem exercido quer no PE, quer na própria Variante Angolana do Português (VAP), nos vários níveis de descrição linguística, fundamentalmente no enriquecimento lexical. Contudo, sempre que for necessário, não escusamos de recorrer a exemplos de outras línguas angolanas de origem africana no intuito de os diversificar (Nzau, 2011, p.64).
}

Em conformidade com Bagno (2015, p.27), o Português, embora seja uma única língua, não está isento de variações de vária ordem devido ao "alto grau de diversidade e de variabilidade, a extensão territorial do país - que gera as diferenças regionais, bastante conhecidas e também vítimas, algumas delas, de muito preconceito". Bagno tece estas considerações sobre o Português do Brasil (PB), porém, a situação descrita por ele, encaixa-se perfeitamente no caso do PA. Assim, procuramos descrever alguns níveis em que a variação linguística se manifesta no PA.

\subsection{Variação ao nível fonético}

A descrição da variação ao nível fonético ocorre na pronúncia de cada comunidade linguística tendo em atenção à região, o que pode resultar da influência e/ ou contacto com outras línguas. As línguas nacionais têm uma influência muito grande no PA. A variação fonético-fonológica pode fornecer-nos informação que nos levam a perceber a região de proveniência do falante. Observemos os casos que se seguem:

- Ocorrência de substituição do fonema /r/ por /1/ e vice-versa, situação motivada pela ausência do /r/ no sistema fonológico do Kimbundu:

1 - Substituição da vibrante [r] pela lateral alveolar [1]: Aloz [elóf] em vez de Arroz; Celeveja [sirlivéze] em vez de Cerveja.

2 - Substituição da alveolar [1] pela vibrante [r]: Arguma [rrgúme] em vez de Alguma; Argarismo [ergerífmu] em vez de Algarismo.

- Pré-nasalização em posição inicial da palavra por via de inserção de:

3 - Consoante nasal [n] antes da oclusiva dental vozeada [d], como se pode verificar nos casos que se seguem: 
Ndobrar [" ${ }^{\mathrm{N}}$ obrár] — Dobrar; Ndois [" $\left.{ }^{\mathrm{n}} \mathrm{j} f\right]$ — Dois.

Assim sendo, são distinguíveis os falantes da região norte e os falantes da região sul do país. Verificam-se alteração na pronúncia dos falantes da região sul resultante de supressão da oclusiva bilabial não-vozeada [p] pela oclusiva bilabial vozeada [b], como por exemplo, em vez de compra estes dizem combra. Além disso, no caso da região norte, pode-se observar a supressão de um $/ \mathbf{r} /$ nos casos de uso do dobro /r/, como por exemplo, ao invés de carro os angolanos da região norte do país dizem caro e os do sul têm tendência a adição de /n/ no princípio da palavra, em vez de dá dizem ndá, por exemplo.

\subsection{Variação ao nível morfossintático}

No que se refere à variação ao nível morfossintático, destaca-se que o Kimbundu é uma língua prefixal visto que a designação do singular e plural acontece no início da palavra, o que não se verifica na língua portuguesa. Em torno deste assunto, Mingas (2007, p.66) afirma que as línguas bantu agrupam-se em nominais, que se encontram organizados em classes, representadas por grupos paritários de prefixos, situação não observável ao português. Deste modo, denota-se a seguinte variação ou "desvio da norma" em relação à norma do PE:

- O usado no PE:
a) - Doem-me os pés
b) - Vigia as crianças

- O uso numa variedade de PA:
a) - Os péø me dói
b) - Vigia as criançaø

Os exemplos que acabamos de apresentar revelam que o falante angolano raciocina dentro da lógica da sua língua materna. Para ele, o artigo português pode confundir-se com o prefixo e a sua função na língua materna (Marques, 1983 apud Nzau, 2011, p.69). Fica claro que nessa variedade do PA existe nulidade de concordância em número entre os atualizadores (os artigos definidos) e os nomes.

Com efeito, para o locutor de Kimbundu, a marca do plural (o morfema /s/ em português) acrescentado ao atualizador é suficiente para indicar o plural do nome (Mingas, 2007). As regras estabelecidas pelo Kimbundu indicam que a flexão ocorre nos prefixos enquanto que no português é nos sufixos. Mingas (2007), Miguel (2014), Adriano (2015) sustentam que ocorrem fenômenos frequentes na questão do nominal complemento directo/indirecto, resultado da ausência do pronome enclítico como acontece no português europeu:

VPA

Posso gritar, lhe prendem

Eu lhe vi deitado [...]
PE

Posso gritar, e prendem-no

Eu vi-o deitado [...] 
Essas particularidades do Kimbundu são transportadas de forma inconsciente para o PA e se refletem nele como uma das características que o distingue do PE. As frases do PA são consideradas agramaticais pela norma do PE. Assim, as descrições acima espelham as características do uso pronominal no contexto angolano. Esta forma de uso, de certo modo, contrasta com a norma e, para os professores que olham simplesmente para a norma prescritiva da língua, consideram esta forma errada. Estas realizações pronominais são utilizadas em diversos contextos e por pessoas de vários extratos sociais.

\subsection{Variação ao nível semântico}

No que tange aos aspectos semânticos, percebe-se que se cinge em estudar os diferentes sentidos que as palavras podem ter, isto é, encontra-se nas palavras um novo sentido no PA para além do que já possuía no PE. Vejamos os exemplos descritos por Nzau (2011, p.71-72):

\section{[[A panela dormiu no quintal]]}

Para este caso, denota-se que a frase é motivada pela interferência das línguas nacionais com o PE. Assim, a expressão [dormiu] carece de um ser animado e a panela não pode "dormir ou acordar", trata-se de um ser inanimado. Por exemplo:

Comeu o dinheiro do Senhor

A realidade sociolinguística angolana espelha o exemplo em questão, pois embora este poder variar em função dos estratos sociais, isto é, os que têm um maior poder financeiro tendem a controlar/monitorar a fala em lugares que envolvem esta classe alta. Para o PE, a frase seria da seguinte forma: "Gastou o dinheiro do Senhor”. Esse enunciado no português angolano resulta da influência da língua materna, que seria escrita da seguinte maneira "Kudya kitadi kya [...]" (recorrendo a uma tradução literal seria "comer o dinheiro de [...]". Todavia, ocorre uma mudança semântica do verbo "comer" para incluir o sentido de "gastar" (Nzau, 2011, p.72).

\subsection{Variação ao nível lexical}

O Kimbundu é tido como a língua que mais empréstimo cedeu ao PA através de verbos e de nomes, o que permite estabelecer diferenças com o PE, visto que o sistema lexical da língua perpassa a experiência cultural da sociedade em que esta se insere. Biderman (apud Nzau, 2011, p.73) sustenta que "cada língua traduz o mundo e a realidade social segundo o seu próprio modelo, refletindo uma cosmovisão que lhe é própria, expressa nas suas categorias gramaticais e lexicais". Deste modo, verificando-se a coabitação linguística, ocorrerá sempre casos de interferências das línguas nacionais no português. Verificam-se as seguintes 
constatações lexicais que o Kimbundu dispôs ao português e que foram descritos por Mingas (2007) e Nzau (2011):

\begin{tabular}{|c|c|c|}
\hline Kimbundu & PA & PE \\
\hline Kubanza & banzar & reflectir, pensar \\
\hline kukoxila & cochilar & dormitar \\
\hline kasula & caçula & filho/a, irmã/o, mais novo/a \\
\hline kambuta & cambuta & anão, de pequeno porte \\
\hline Ndenge & Ndengue & indivíduo de idade inferior, criança \\
\hline
\end{tabular}

Ora, perante a realidade de variação linguística - tal como as descritas acima, quer fonética, morfossintática, semânticas e lexical-, Bortoni-Ricardo (2004, p.8) sustenta que em

Todos esses casos, estamos diante de diferenças e não de "erros". A noção de "erro" nada tem de linguístico - é um (pseudo) conceito estritamente sociocultural, decorrentes de critérios de avaliação (isto é, dos preconceitos) que os cidadãos pertencentes à minoria privilegiada lançam sobre todas as outras classes sociais. Do ponto de vista estritamente linguístico, o erro não existe, o que existe são formas diferentes de usar os recursos potencialmente presentes na própria língua.

\section{Desconstruindo dogmas: ensinar a língua pela diversidade}

Os estudos de Bagno mostram claramente que o preconceito linguístico é tanto mais poderoso porque, em grande medida, "ele é invisível, no sentido de que quase ninguém se apercebe dele, quase ninguém fala dele, como exceção dos raros cientistas sociais que se dedicam a estudá-lo." (Bagno, 2015, p.22). Em nossa sociedade angolana, pouquíssimas pessoas reconhecem a existência do preconceito linguístico e, muitas vezes, ninguém se apercebe da gravidade do assunto, como um sério problema social. Por isso, as escolas ainda proíbem o uso das línguas locais no espaço escolar e qualquer tentativa seria desafio às normas do Estado. O resultado disse é a reprovação tanto na escola quanto na vida profissional. Bagno advoga que "enquanto não se reconhece sequer a existência de um problema, nada se faz para resolvê-lo" (Bagno, 2015, p.22).

O ensino da língua em Angola baseado no normativismo, fixado à gramática tradicional do PE, não espelha a realidade linguística angolana, como se observou nas descrições acima. A realidade de variação linguística permitiu que surgisse o PA, mas tem sido motivo de segregação por parte dos professores que não o reconhecem como variação linguística de uso diário pelos seus falantes. A situação descrita acima tem estimulado que estas abordagens sejam excluídas na sala de aula, o que sustenta o preconceito linguístico. A língua vive um processo gradativo, evolutivo e suas práticas envolvem fator histórico, geográfico, social, 
cultural, etc. o que implica dizer que não se pode "encarar a língua como um objeto descontextualizado, inerte, congelado, morto, fora do tempo, fora do espaço, independente das pessoas que a falam" (Bagno, 2015 p.148).

$\mathrm{Na}$ verdade, o Estado é chamado a desenvolver políticas que tenham em atenção a realidade linguística do país e o professor é chamado a abandonar o normativismo exacerbado, a desmistificar o ensino, visto que o Português utilizado nas diversas esferas da vida social em nada relaciona-se ao PE, por isso, pensamos que se deve recorrer ao ensino voltado a "uma pedagogia que é culturalmente sensível aos saberes dos educandos está atenta às diferenças entre cultura que eles representam e a da escola, e mostra ao professor como encontrar formas efetivas de consciencializar sobre as diferenças" (Bortoni-Ricardo, 2004, p.38).

O ensino da língua portuguesa em Angola, hoje, não passa de uma descrição de categorias gramaticais. Isso inibe o aluno de contribuir com suas práticas de uso diário da língua. As categorias gramaticais que são estudadas acabam por limitar o aprendizado, despreza-se o processo evolutivo e dinâmico da língua e se reforça uma abordagem de ensino de língua alheia à realidade de uso, assumindo a língua como entidade homogênea, o que não reflete a verdade. De acordo com (Bagno, 2007, p.33), "a variação linguística não entrava nos planos do ensino ela era insensível e inaudível, relegada ao submundo do erro". Percebe-se, pelo excerto acima, que o ensino da gramática normativa não propicia um aprendizado eficaz como defendem alguns linguistas, referindo que "os usos fora do parâmetro culto não indicam despreparo linguístico, ignorância gramatical, mas, ao contrário, indicam empenho por ser eficiente e poder garantir o sucesso da interação. A transgressão, neste caso, vira recurso; vira tática para assegurar uma maior eficiência comunicativa" (Antunes, 2014, p.99).

Relativamente ao menosprezo de uma abordagem que contempla a variação linguística e o ensino focalizado somente à gramática tradicional, prática comum que os professores levam em sala de aula, Soares (1999) apud Bagno (2001, p.82-83) sustenta que

\footnotetext{
é preciso que a escola se consciencialize de que o verdadeiro papel do ensino de língua não é ensinar uma norma-padrão obsoleta e repressiva, não é "ensinar gramática", isto é, levar o aluno a decorar nomes e definições para em seguida fazer análise morfológica e sintáctica mecânica e estéreis. O verdadeiro objectivo da educação linguística é oferecer condições para o ininterrupto letramento dos estudantes: para que ele desenvolva cada vez mais e melhor as habilidades de leitura e de produção de textos e possam se inserir plenamente na cultura letrada.
}

As investigações relacionadas à Sociolinguística em Angola carecem de se desenvolver de forma célere, conjuntamente com a definição da norma do português 
Angolano, de modo que as questões de variação linguística sejam encaradas e estudadas em sala de aula sem qualquer marginalização ou estigma. A língua espelha a heterogeneidade e, no PA, observam-se processos variáveis e instáveis que a sociolinguística se propõe a analisar. Deste modo, fica claro que a língua não é um produto acabado, ela sofre mudanças ao longo do tempo, por esta razão, "a língua não está registrada por inteiro nos dicionários, nem suas regras de funcionamento são exatamente (nem somente) aquelas que aparecem nos livros chamados gramáticas. É mais uma ilusão social acreditar que é possível encerrar num único livro a verdade definitiva e eterna sobre uma língua" (Bagno, 2007, p.36).

Como deve atuar um professor de língua perante a norma-prescritiva e a variação linguística? O desafio do ensino hoje deve estar voltado aos olhares analítico-reflexivo sobre os usos reais da língua que valorizam as formas de falar de cada aluno, visto que

o verdadeiro problema é considerar que existe uma língua perfeita, correta, bem-acabada e fixada em bases sólidas, e que todas as inúmeras manifestações orais e escritas que se distancie desta língua ideal são como ervas daninhas que precisam ser arrancadas do jardim para que as flores continuem lindas e coloridas (Bagno, 2007, p.36).

Deve-se desconstruir as visões que se encaminham à concepção considerada "certa", mas que em nada corresponde à realidade do uso da língua. A perspectiva do ensino da língua em uso é vista por Antunes (2014, p.148-150) da seguinte maneira:

a) Aprendizagem de uma gramática contextualizada que valorize os usos linguísticos - orais e escritos - que de fato são feitos; não uma gramática que se impõe pelo que está "assentados nos livros";

b) Aprendizagem vinculada ao exercício da compreensão de sentidos e intenções: relacionar os itens gramaticais permitindo que se estabeleça uma significação macro ou microestrutural do texto, permitindo que se compreenda os efeitos de sentidos, funções que desempenham, por que acontecem e como acontecem, nessa ou naquela posição;

c) Aprendizagem descentrada do plano de abstração: centrado no concreto da existência; isto é, observação da língua real, efetiva quer na literatura, quer na imprensa, no uso diário nos diversos contextos sociais;

d) Aprendizagem crítica: que investiga e não se limita àquilo que é a norma da gramática tradicional, vinculada a um ensino que desenvolva habilidade de "perguntar" e não, apenas, a de "responder", permitindo que se levantem hipóteses, rejeitando dogmatismo ou certezas absolutas e aceitando o desafio de desmistificar 
a tradição de gramáticas e de gramáticos;

e) Aprendizagem decorrente de um ensino "honesto" : que respeite a realidade dos dados - suas potencialidades e seus limites - assume postura mais descritiva que normativa ou prescritiva;

f) Aprendizagem que vê a "norma linguística" mais pelo ângulo de regularidade, do habitual, do que pelo outro da obrigatoriedade;

g) Aprendizagem aberta, flexível: deve propiciar à aceitação das alterações e mudanças que vão surgindo e se sedimentando em todos os domínios do vocabulário e da gramática;

h) Aprendizagem bem fundamentada: deve perceber a língua em diversos pontos de vista, reconhece a correção gramatical não como algo intrinsecamente bom e legítimo, mas como decorrência de valores simbólicos, meramente ideológicos e culturais, dos grupos humanos;

i) Aprendizagem plural: que acolhe a diversidade linguística como algo inevitavelmente constitutivo das realidades humanas, rejeita, entre outras, a crença de que "o povo assassina a língua" ou de que "a língua, pela ação do povo, corre sérios perigos";

j) Aprendizagem vinculada a um ensino instigante: que em cada momento, estimule a compreensão, a fluência, o intercâmbio, a atuação verbal como forma de participação nossa na construção de um mundo, inclusive linguisticamente, mais justo, mais humano, mais tolerante e respeitador;

k) Aprendizagem libertadora: que leva os alunos a crescerem em sua auto-estima, em sua autonomia comunicativa; que leva os alunos a acreditarem em suas potencialidades como "seres comunicativamente competentes", capazes de moverem, com pleno êxito, no mundo da interação sociocomunicativa;

1) Aprendizagem e ensino libertadores também para os professores, que lhes possibilitem o exercício não apenas de "transmitir conhecimento", mas, sobretudo, de "gerar conhecimento", de descobri-los, de fazê-los e refazê-los, em sintonia com o jogo necessário à vida de, permanentemente, aprender e desaprender;

m) Aprendizagem, enfim, que abre horizontes: que leva os alunos a descobrirem, ao lado da complexidade da linguagem, o seu fascínio e o imenso lucro outorgado ao homem pela faculdade de linguagem; que leva os alunos e professores a descobrirem a presença da linguagem em toda construção humana.

Ora, os passos descritos acima fazem com que os professores não estigmatizem os alunos, permitindo-os, deste modo, que haja em sala de aula um processo de ensino refletivo e de discussão sobre a variação linguística que a língua apresenta entre PE e o PA. Este é o desafio que "cada um de nós, professor/a ou não, precisa elevar o grau da própria autoestima linguística: recusar com veemência 
os velhos argumentos que visem menosprezar o saber linguístico individual de cada um de nós. Temos de nos impor como falantes competentes de nossa língua" (Bagno, 2015, p.166).

Desta forma, a variação e mudança linguística descrevem o quanto a língua é natural e heterogênea, que se vai alterando mediante o uso. O professor é chamado a promover um ensino desmistificado, que se desvincula no que Bagno (2015) considera por Santíssima Trindade, "a gramática tradicional e ou normativa/ prescritiva, a pedagogia tradicional/métodos tradicionais de ensino" e afincada em livros didácticos que descrevem o (PE). É necessário e urgente que se leve à sala de aula um ensino que valorize a questão da variação linguística como elemento indispensável da língua bem como motivador de reflexão. Assim, o ensino de língua deve debruçar-se sobre aspectos que analisem a norma-prescritiva e a norma-objectiva de modo a desconstruir a ideia de que existem "normas inerentemente melhores, mais bonitas, mais lógicas, mais puras que outras". O prestígio vem por conta de fatores sociais apenas, e não em decorrência de algum fator linguístico. Devemos rejeitar a impressão de que aqueles que falam fora da norma culta/prescritiva são "rudes, poucos inteligentes, ignorantes e incultos" (Antunes, 2007, p.100).

Fica claro que a missão da escola é promover a análise e a reflexão crítica sobre a língua em uso, garantindo aos alunos o ensino voltado ao uso, incluindo o contexto. O professor é chamado a despir-se das ideologias da gramática prescritiva que tem motivado o preconceito e, consequentemente, a desigualdade social, adotando métodos pedagógicos que ensinam a língua tendo em atenção a sua variação, pois é "compromisso político de converter a sociolinguística em um instrumento de luta contra toda forma de descriminação e de exclusão social pela linguagem" (Bortoni-Ricardo, 2004, p.10).

\section{Conclusão}

O contacto entre as línguas nacionais e o Português influenciou a caracterização atual do PA que é nutrido de variação linguística e, por esta razão, Angola é considerado um país linguisticamente heterogêneo. Esta realidade de variação linguística não deve ser vista como um problema por parte dos professores, uma vez que o verdadeiro problema é

discernir do que faz parte desse padrão e adotar uma visão não purista, de flexibilidade, de abertura, para incorporar as alterações que vão surgindo; o problema é, ainda, não julgar essas mudanças como, simplesmente, provas de decadências da língua e, assim, não subestimar ou não ridicularizar aqueles que fogem a esse padrão socialmente prestigiado (Antunes, 2007, p.101). 
$\mathrm{Na}$ atividade docente, o professor é chamado a promover o ensino tendo em atenção as diferenças de uso da língua dos alunos. Deve-se manter o respeito pela diversidade linguística e se evitar desprestigiar uma ou outra forma de falar, visto que a própria língua sofre alterações em função do tempo, o que acentua ainda mais as situações de variação. Para este caso, torna-se necessária a adoção de uma cultura pedagógica que valorize a diferença de modos a manterem em funcionamento o normativismo e a variação linguística nas discussões em sala de aula, partindo da conscientização que o professor deve fazer ao seu educando. Portanto, não se pode encarar o ensino da língua somente afincado à gramática normativa/prescritiva como a única e a que transmite o que é "certo" e os demais acontecimentos na língua vistos como "erro". Bagno (2015, p.111) sustenta que “[...] muito preconceito decorrente de valor atribuído às variedades padrão e ao estigma associados a variedades, consideradas inferiores ou erradas pela gramática. Essas diferenças não são imediatamente reconhecidas e, quando são, são objeto de avaliação negativa".

O ensino de língua ainda se sustenta no uso doutrinário da gramática tradicional/prescritiva, afincada no normativismo que promove por meio de suas ideologias o preconceito linguístico que provoca a fuga de muitos alunos às aulas. Esta realidade é decorrente das políticas educacionais que o Estado adota. A variação linguística que caracteriza o PA não pode ser vista como aleatória visto que cada mudança tem suas motivações. Todavia, a doutrina do ensino baseado à gramática tradicional promove dificuldades no sistema de aprendizagem, bem como coíbe o aluno de se sentir à vontade nas aulas. Esta prática de coibição linguística encaminha-se para a coibição social do indivíduo, o que, de certa forma, origina a desigualdade social. A escola deve ser a via para dirimir visões que estigmatizam as variações linguísticas, pois estas passam a descrição da língua em uso, o dia-a-dia do indivíduo e/ou aluno. Assim sendo, o ensino deve primar por um ensino em que o aluno compreenda o funcionamento da língua, tendo presente as suas várias mudanças, bem como a adopção de um modelo de ensino que comtemple os aspectos inerentes a variações linguísticas.

\section{Referências}

Adriano, Paulino Soma. A crise normativa do português em Angola: clitização e regência verbal: que atitude normativa para o professor e revisor?, Luanda: Mayamba, 2015.

Antunes, Irandé. Muito além da gramática: por um ensino de línguas sem pedras no caminho. São Paulo: Parábola, 2007.

Antunes, Irandé. Gramática contextualizada: limpando “o pó das ideias simples”, São Paulo: Parábola, 2014. 
Bagno, Marcos. Nada na língua é por acaso: por uma pedagogia da variação linguística, São Paulo: Parábola, 2007.

Bagno, Marcos. Preconceito linguístico. São Paulo: Parábola, 2015.

Revista de Estudos Linguísticos, Juiz de Fora: v.5, n. 2, p.71-83, 2001. Disponível em: www. ufjf.br/revistaveredas/files/2009/12/cap063.pdf. Acesso em: 15 jun.2005.

Bortoni-Ricardo, Stella Maris. Educação em língua materna: a sociolinguística na sala de aula, São Paulo: Parábola, 2004.

Domingos, Manuel da Silva. Nasalidade vocálica em português: Pistas para identificação forense de falantes. 2011.189p. (Dissertação de Mestrado), Universidade de Lisboa, Departamento de Letras, Lisboa, 2011.

Instituto Nacional de Estatística. Recenseamento geral da população e da habitação. Luanda: INE, 2014.

Labov, William. Padrões sociolinguísticos, São Paulo: Parábola, 2008.

Miguel, Maria Helena. Dinâmica da pronominalização no português de Luanda, Luanda: Mayamba, 2014.

Mingas, Amélia. Interferência do kimbundu no português falado em Lwanda. Luanda: Chá de Caxinde, 2007.

Monteagudo, Henriques. Variação e norma linguística: subsídios para uma (re) visão. In. Lagares, Xoán Carlos; Bagno, Marcos (Org.), Políticas da norma e conflitos linguísticos. São Paulo, Parábola, 2011.p.15-48.

Nzau, Domingos Gabriel Ndele. A lingua portuguesa em Angola: um contributo para o estudo da sua nacionalização. 2011, 203p. (Tese de Doutoramento), Universidade de Beira Interior, Departamento de Letras, Covilhã, 2011. 